Yearbook of the Maimonides Centre for Advanced Studies 2019 


\section{Yearbook of the Maimonides Centre for Advanced Studies}

Chief Editor

Giuseppe Veltri 
Yearbook of

the Maimonides Centre

for Advanced Studies 2019

Volume Editor

Yoav Meyrav

DE GRUYTER 
The Yearbook is published on behalf of the Maimonides Centre for Advanced Studies

ISBN 978-3-11-060332-3

e-ISBN (PDF) 978-3-11-061883-9

e-ISBN (EPUB) 978-3-11-060737-6

\section{(cc) BY-NC-ND}

This work is licensed under the Creative Commons Attribution-Non Commercial-No Derivatives 4.0 Licence. For details go to http://creativecommons.org/licenses/by-nc-nd/4.0/.

\section{Library of Congress Control Number: XXX}

\section{Bibliographic information published by the Deutsche Nationalbibliothek} The Deutsche Nationalbibliothek lists this publication in the Deutsche Nationalbibliografie; detailed bibliographic data are available on the Internet at http://dnb.dnb.de.

(C) 2020 Walter de Gruyter GmbH, Berlin/Boston Cover image: Staats- und Universitätsbibliothek Hamburg, Ms Cod. Levy 115, fol. 158r: Maimonides, More Nevukhim, Beginn von Teil III. Printing and binding: $\mathrm{CPI}$ books $\mathrm{GmbH}$, Leck 


\section{In Memoriam Roi Benbassat}


